International Journal of Linguistics, Literature and Translation (IJLLT)

ISSN: 2617-0299 (Online); ISSN: 2708-0099 (Print)

DOI: $10.32996 / \mathrm{jjllt}$

Journal Homepage: www.al-kindipublisher.com/index.php/ijllt

\title{
A syntactic and Semantic Analysis of the Tèż Verb Phrase
}

Gbene-Nnah, Dumdebabari

Student, Department of Linguistics and Communication Studies, Faculty of Humanities, University of Port Harcourt, Rivers

State, Nigeria.

Corresponding Author: Gbene-Nnah, Dumdebabari, E-mail: dum.g@yahoo.com

\section{ARTICLE INFORMATION}

Received: November 05, 2020

Accepted: December 01, 2020

Volume: 3

Issue: 12

DOI: $10.32996 /$ ijllt.2020.3.12.4

\section{KEYWORDS}

Tè่̇, Verb, phrase, dependents, complements, adjuncts

\section{ABSTRACT}

This study descriptively analyses the syntactic and semantic features of the Tغ̇ं verb

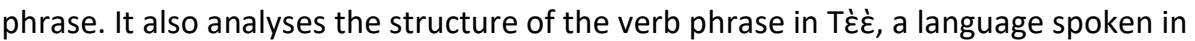
Tai Local Government Area of Rivers State. The verb phrase is a syntactic unit composed of at least one verb and its dependents and other modifiers but not always including the subject. The verb is central in every language coupled with the fact that it is the most important and widely described phrase because the structure of and the meanings expressed in many languages revolves around the verb word. The research focuses to explore the peculiarities of the verb phrase in the language focusing basically on the structure of the verb phrase and the meaning

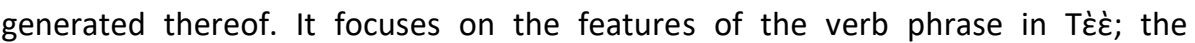
constituent that make it up, their arrangement as well as the meaning attributed by such arrangements. The primary data for this work were collected using the intuitive knowledge of the researcher as a native speaker verified with unstructured interview with competent native speakers. From the analysis of the data collected, the researcher discovered that the verb phrase in Tì่ can have various configurations. The constituents that may combine with the head of a verb phrase to project it into a larger structure are the complements and the adjuncts. The complement of the verb phrase can be the noun phrase, the prepositional phrase and the inherent complement. The adverbial functions both as complement and adjunct in the language.

\section{Introduction}

Phrases are syntactic structures made up of the head element with or without dependent elements. Dependent elements may precede or follow the head (Aronoff \& Reese-Miller, 2006; Crystal, 2010; Fromkin \& Hyams, 2010; O'Grady, Archibalds, Aronoff, \& Rees-Miller, 2005; Yule, 2006). The head determines the type of phrase and how the dependent elements organise and function in the phrase (Aronoff \& Reese-Miller, 2006; Crystal, 2010; Fromkin \& Hyams, 2010; O'Grady, Archibalds, Aronoff, \& Rees-Miller, 2005). There are different types of dependent elements conditioned by the type of phrase (Aitchison, 1992; Aronoff \& Reese-Miller, 2006; Crystal, 2010; Fromkin \& Hyams, 2010; Lyons, 1992; O'Grady, Archibalds, Aronoff, \& Rees-Miller, 2005; Yule, 2006). Dependent elements occur in a given order in relation to the head and relate to the head in different ways. In a verb phrase, some dependent elements are needed by the head to complete its meaning, while others are not need by the head verb. Dependent elements that the head verb needs for its meaning to be complete are closely linked to the it, while those that the head verb does not need are loosely linked to it.

T'́̀ं is one of the languages that make up the Kegboid group of languages (Williamson and Blench 2000). Scholars like Anyanwu and Omego 2011 have described the grammar of the language without much emphasis on the syntax of the language. That is the only attempt on the description of the grammar of the language. The current work is set to explore the peculiarities of the verb phrase in the language focusing basically on the structure of the verb phrase and the meaning

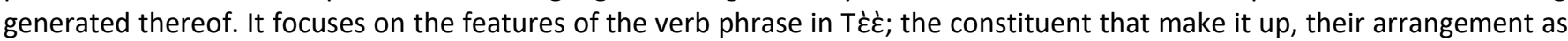
well as the meaning attributed by such arrangements.

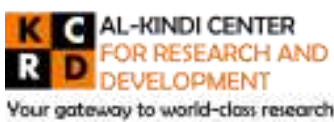

Published by Al-KindiCenter for Research and Development. Copyright (c) the author(s). This is an open access article under CC BY license (https://creativecommons.org/licenses/by/4.0/) 


\section{Literature Review}

\subsection{The Phrase}

the phrase is a group of words which are joined following the rules of the grammar of the language (Ndimele, 1999). A phrase is also seen as a single element of structure typically containing more than one word and lacking the subject-predicate structure (Crystal, 2010). Huddleston (1984:26) sees the phrase as "a type of construction containing a head element optionally accompanied by one or more dependents". Thus, a phrase is a group of words joined by the rules of grammar of a language without subject and predicate.

\subsection{The Notion of the Head}

the notion of the head is very important in the discussion of phrases. It is seen as syntactically central; the head is the most central part of a construction because it determines the meaning of the entire phrase. All the other word in a construction depend on the head (Ndimele, 1999). Words which are part of the phrase and which come before the head are called prehead whereas words which come after the head are called the post head. He added that the head determines the nature of the entire phrase.

Tallerman (2005) further explains that the head determines the nature of the elements that occurs in its phrase. He added that a phrase takes its name from the word functioning as the head. Depending on the head, the following phrases exist; noun phrase (NP), verb phrase (VP), prepositional phrase (PP), adjective phrase (Adj.P), and the adverbial phrase.

\subsection{The Verb Phrase}

The term 'verb phrase' is used in two senses according to Crystal (2010). The first sense is from the traditional point of view which refers to a group of verbs which together have the same syntactic function as a single verb. The second sense is from the generative point of view which sees the verb phrase as being equivalent to the whole of the predicate of a sentence; as is clear from the expansion of S as NP + VP in phrase structure grammar. Bussmann (1996:930), argues that "the predicate is not the same with the verb phrase in generative transformation grammar since unlike the verb phrase, in the tree diagram, it dominates not only the verb but also all elements (object) dependent on the verb".

Structurally, a verb phrase is the largest expressions or the maximal projection of the verb. Other units of the grammar such as the NP and/or the PP, the AdjP and the AdvP can combine with the verb to form the VP.

Crystal (2010) presented two views on the verb phrase. He looked at it from the traditional and generative perspective. He stated that the verb phrase traditionally refers to "a group of verbs which together have the same function as a single verb". He went further by giving the following examples: 'is coming', 'may be coming', 'get up to', stating that only one verb in the group is the main verb while others are subordinate to it. On the other hand, from the generative point of view, he describes the verb phrase as having a broader definition. He equals the verb phrase to the whole of the predicate slot of the sentence as represented in the schema below:

S $N P+V P$

In the same manner, the verb phrase is determined by the sub-categorization features of the verb. For instance, a verb can be transitive in which case it selects or co-occurs with or without adverbials. For instance, laugh, play, see, give and show.

\subsection{Constituents of the Verb Phrase}

Fromkin and Rodman (1993:204) states that a verb phrase may consist of:

A verb alone

The boy slept

VP

A verb followed by a noun phrase

The child found the puppy

$\mathrm{VP} \longrightarrow \mathrm{V}+\mathrm{NP}$

A verb followed by a noun phrase followed by a prepositional phrase

The woman put the cake in the cupboard 
$\mathrm{VP} \longrightarrow \mathrm{NP}+\mathrm{PP}$

A verb followed by a prepositional phrase

The child laughed at the puppy

VP

$$
V+P P
$$

\section{Methodology}

The data were generated from the intuition of the researcher as a native speaker. However, the study does not rely solely on this method in order to avert being subjective (rather than objective), which is a major disadvantage of sole reliance on intuition, hence, the additional unstructured interview was also used as a method of eliciting primary data and they were also engaged in informal narrative discussions. Relevant syntactic structures were elicited from the discourse and compared with similar structures derived intuitively. A descriptive method was utilized in the study since it is language based. This is best for

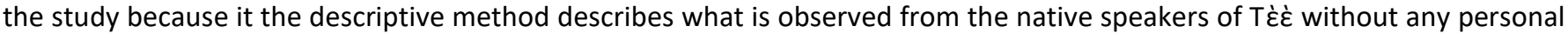
bias.

\section{Results and Discussion}

\section{1 verb phrase in Tغ่̀े}

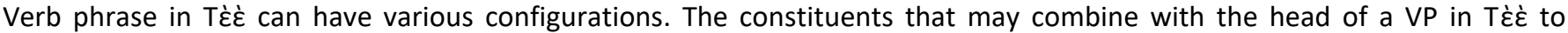
project it into a larger structure are the complements or adjuncts. The choice of the complements is dependent on the semantic and syntactic properties of the head (the verb).

Structurally, Tغ̇̀̇ VP can take any of the following forms.

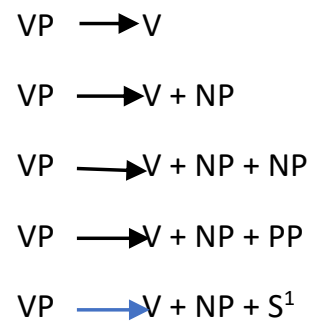

Schematically, Tee VPs are formed according to the following format:

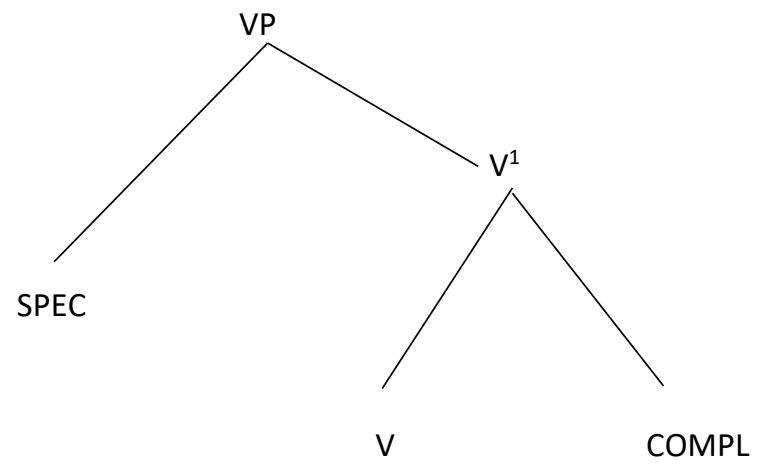

$\begin{array}{llll}\mathrm{VP} & \mathrm{SPEC}+\mathrm{V}^{1} & \\ \mathrm{~V}^{11} & \mathrm{~V}^{1} & + & \text { ADJUNCT } \\ \mathrm{V}^{1} & \mathrm{~V} & + & \text { COMPL }\end{array}$

A complement combines with $\mathrm{V}$ to form a $\mathrm{V}^{1}$, an adjunct combines with the $\mathrm{V}^{1}$ to form a higher $\mathrm{V}^{1}$. Hence a $\mathrm{V}$ projection may contain several $\mathrm{V}$-nodes. The specifier combines with $\mathrm{V}^{1}$ to form VP. VP is the maximal projection of $\mathrm{V}$.

Examples

1a) Dum lóp $h^{w}$ áá 
PN wash car

'Dum washed the car'

b) Dum lóp $\quad h^{w}$ áá bie búlẹe

PN wash car in outside

'Dum washed the car in the compound'

c) Kiisi ne kpìgì $\quad \mathrm{Nia}$

PN give money $\mathrm{Nia}$

'Kiisi gave Nia money'

\subsection{Tee Verb Phrase Complements}

As stated earlier, the verb is the head of the verb phrase and it is the only obligatory constituent of the Tغ่غे.

2a) bà beè dé zĩ̃á

3PL PST eat food

'they ate the food'

b) *bà beé dé

3PL PST eat

3a) kobo beé $h^{w}$ é lo gbó

PN PST kill the dog

'Kobo killed the dog'

b) *Kobo beé $h^{w}$ é

PN PST kill

the ungrammaticality of ( $2 b)$ and (3b) result from the absence of an accompanying complement.

VP $\longrightarrow V$

On the other hand, the verb can stand as the only obligatory element in a verb phrase as exemplified below:

4a) Ledum beé lú

PN PST come

“Ledum came'

b) à beé ?ú

3SG PST die

'He died'

The verbs lú 'come' and ?ú 'die' as shown above, does not allow a following object (NP). This accounts for the ungrammaticality of the following sentences where the verb lú 'come' and ?ú 'die' are followed by the objects.

5a) *Ledum beé lú lo gbó

PN PST come the dog

b) *a beé ?ú lo zĩ̃a 
3SG PST die the food

In what follows, the various complements of the verb phrase in the language is discussed.

\subsubsection{The Noun Phrase Complement}

In T⿱宀乇े, the complement of the verb phrase can be a noun phrase. This is discussed below;

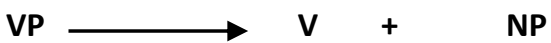

The object complement "occurs in a two-place simple sentence. It is the internal argument, and it is assigned the patient $\theta$ role. An object complement completes the meaning of the object it follows.

6a) Were beé $h^{w}$ é póró

PN PST kill fish

'Were killed a fish'

b) Bebu beé zìbásî́ Bemu

PN PST slap PN

'Bebu slapped Bemu'

In a construction where there are several $\mathrm{V}$-bars, the object complement combines with the $\mathrm{V}$ to form the lowest $\mathrm{V}^{\mathrm{l}}$ projection (the object is dominated by the VP).

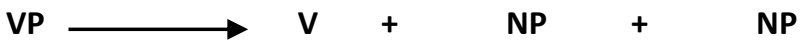

7a) Bà bọ̀gẹre kpìgì lo nwà̀

3PL lend money the woman

'They lent the woman money'

b) bà bògère ye kpìgì

3PL. lend 3SG money

'They lent her money'

c) Mama beé ne hyáà piyá-tokpá

PN PST give yam people-school

'Mama gave some students yam'

d) Mama beé ne wa hyáà

PN PST give 3PL yam

'Mama gave them yam'

(7a-d) above shows the structure of a verb phrase when it has two object complements. It is observed that nothing intervenes between a case-assigner and a case-receiver. The structure of the verb phrase with double object is that the direct object is followed by the indirect object or the reverse (indirect object before direct object) when the indirect object is a proform as in $(7 b, d)$ above.

In the case where the VP occurs with double objects, there is a certain subcategory of verbs, change of position verbs, which have the capacity to assign two $\Theta$-roles to their internal argument the preposition 'bie' glossed 'in the' is used as in (8) below.

8a) Nornu beé bọgẹ̀rẹ kpìgì Barida bie kedu

PN PST lend money PN in the market 
'Nornu lent some money to Barida in the Market'

\subsubsection{Propositional Phrase Complement}

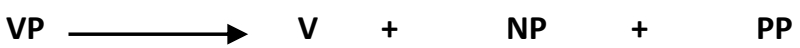

In Tr̀ं , it is possible for a prepositional phrase to function as the complement of a verb.

7a) póro dé no ákwíríká

Fish be on fish-rack

'the fish is on the fish-rack'

b) lo kpá de bu bèrè

det. Book be in bag

'the book is in the bag'

The $\mathrm{V}$ and the PP projects to the $\mathrm{V}^{\prime}$ thus placing them on the same terminal nodes. This indicates that PP is complement of the $\mathrm{V}$.

\subsubsection{Finite Clause Complement}

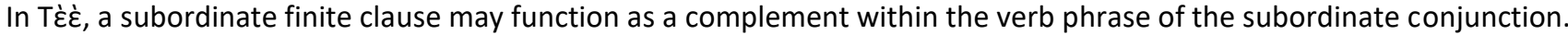

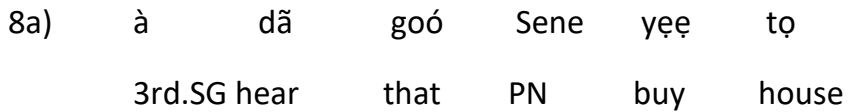

'she heard that Sene bought a house'

$\begin{array}{llllll}\text { b) bà } & \text { sũà } & \text { goó } & \text { mे } & \text { ga lu hyõóe } \\ \text { 3rd.pl know } & \text { that } & \text { 1st.sg } & \text { PROG. Come tomorrow }\end{array}$

'they knew that I was coming tomorrow'

\subsubsection{Adverbials as Complements}

Adverbials can perform both complement and adjunct function. Here, adverbials are discussed as complements not as adjuncts. In T⿱亠乂 $\dot{\varepsilon}$, adverbials complementing the head verb occur in a position immediately after the verb. They combine with the $\mathrm{V}$ to form the $\mathrm{V}^{\prime}$ such that their deletion affects the grammaticality of the construction.

9a)

À yii bu to á

3SG enter in house that

'she enters that house'

b)

ló dòògànù de ànì̀ álékéré

the party be six clock

'the party is at $6 \mathrm{O}^{\prime}$ clock'

10a)

*À yii

She enter

b) * ló dòògànù de

the party be

as mentioned above, the deletion of the adverbials affects the grammaticality of the construction. This is the reason for the ungrammaticality of $(10 a-b)$ as opposed to (9a-b) above. This shows that the adverbials are complements of the verb phrase. 


\subsection{Adverbials as Adjuncts}

In T⿱亠乂 $\dot{\varepsilon}$, adverbials can act as adjuncts. An adjunct can be a prepositional phrase, clauses or a noun phrase.

11a) bà bừù lo kpá bèè số

3PL read the book two time

'they read the book twice'

b) Biaka sú lo bấ lẹè̀ sóó

PN take the pot from kitchen

'Biaka took the pot from the kitchen'

12a) bà bừù lo kpá

3PL read the book

'they read the book'

b) Biaka sú lo bã́

PN take the pot

'Biaka took the pot'

The grammaticality of (12a-b) shows that the deletion of adjuncts does not affect the grammaticality of constructions in the language. This is the major difference between the adverbial complements and the adjuncts.

Another difference between them is that the adverbial complement is closer to the head than the adjuncts as it is observed in $(12 a-b)$ and (11a-b) above. Again, the complement is within the $V^{\prime}$ containing the head $V$ while the adjunct is outside of it.

\subsection{Inherent Complement Verb}

In Tغ่̇, the semantic unity between certain verbs and their accompanying nominals is so strong that these verbs are almost empty without these nominals.

13a) Yii yèm̀

Enter mourning

'to mourn'

b) èmà èp

try check

'to examine'

c) kéé zî́á

stay-away food

'to fast/starve'

d) Úwẹ́ hyóọ́

sing song

'to sing'

e) tẹrẹ kế

drop egg 
'to hatch'

f) bírá máá

bath water

'to bathe'

14a) Lekia yii yèm ye dám

PN enter mourning 3SG husband

'Lekia mourns her husband'

b) Nwií a ga kéé zî́ă

Child this PROG stay-away food

'this child is fasting'

14a-b) contain inherent complement verbs (ICVs). There is nothing intervening between the verb and its inherent complement. The verb root and the inherent complement combine to project as the minimal $\mathrm{V}$. this indicates that they are considered as a single lexical item.

\section{Conclusion}

This study has provided insight into the syntactic and semantic features of the verb phrase, the constituents that make it up, their arrangements as well as the meaning attributed by such arrangement with the aim of adding to the growing literature of the langauge

From the analysis of the data, itw as discovered that the constituent that may combine with the head of the verb phrase in Tغ่̇̀ are complements; the noun phrase, the prepositional phrase and the inherent complement. The adverbial functions both as complement and adjunct in the language. . There are other aspects of the verb phrase in the language and the current researcher recommends further studies into these other aspects.

\section{References}

[1] Anyanwu, O., \& Omego, C. (2011). A grammatical description of the Tee language. Germany: LAP LAMBERT Academic Publishing GmbH \& Co.KG.

[2] Aronoff, M., \& Reese-Miller, J. (2006). The handbook of linguistics. Malden MA: Blackwell.

[3] Bussmann, H. (1996). Routledge dictionary of language and linguistics (2 ${ }^{N D}$ ed.). London: Routledge.

[4] Crystal, D. (2010). The Cambridge encyclopedia of language. Cambridge: Cambridge University Press.

[5] Fromkin, V. R., \& Hyams, N. (2010). An Introduction to Language. Boston: Thomson-Henle.

[6] Fromkin, V., \& Rodman, R. (1993). An introduction to language. Fort Worth: Harcourt Bace Jovanovich.

[7] Huddleston, R. (1984). Introduction to the grammar of English. Cambridge: Cambridge University Press.

[8] Ndimele, O. (1999). Morphology and syntax. Port Harcourt: M\&J Grand Orbit.

[9] O'Grady, W., Archibalds, J., Aronoff, M., \& Rees-Miller, J. (2005). Contemporary linguistics: An introduction (4th ed.). Bedford: Martin's Press.

[10] Tallerman, M. (2011). Understanding syntax. 3rd edn. London: Hodder Education.

[11] Williamson, K., \& Blench, R. (2000). Niger-Congo. In B.Heine and D. Nurse (eds.), African languages: An Introduction, 11-42. Cambridge: Cambridge University Press.

[12] Yule, G. (2006). The study of language. Cambridge: Cambridge University Press. 